\title{
Pengaruh Penerapan Model Discovery Learning terhadap Kemampuan Penalaran Matematis ditinjau dari Pengetahuan Awal Siswa SMP Negeri 3 Tambang Kabupaten Kampar
}

\author{
Linda Rahman ${ }^{1}$, Depi Fitraini' ${ }^{2}$, dan Irma Fitri ${ }^{3}$ \\ ${ }^{1}$ Program studi pendidikan matematika, Universitas Islam Negeri Sultan Syarif Kasim Riau \\ e-mail: depi.fitraini@uin-suska.ac.id
}

\begin{abstract}
ABSTRAK. Penelitian ini merupakan penelitian eksperimen dengan jenis Quasi Experiment dan bertujuan untukmengetahui pengaruh penerapan model discovery learning terhadap kemampuan penalaran matematis ditinjau dari pengetahuan awal siswa SMP Negeri 3 Tambang Kabupaten Kampar. Populasi dalam penelitian ini adalah seluruh siswa kelas VIII SMP Negeri 3 Tambang tahun pelajaran 2017/2018 yang berjumlah 202 siswa dan sampel dalam penelitian ini adalah kelas $\mathrm{VIII}^{4}$ sebagai kelas eksperimen dan kelas $\mathrm{VIII}^{2}$ sebagai kelas kontrol. Pengambilan sampel dilakukan dengan teknik purposive sampling. Teknik analisis data menggunakan uji-t, uji korelasi (pearson product moment) dan anova dua jalan. Berdasarkan hasil analisis data dapat diambil kesimpulan bahwa: 1) terdapat perbedaan kemampuan penalaran matematis antara siswa yang diterapakan model discovery learning dengan siswa yang tidak diterapkan model discovery learning. Hal ini ditunjukkan dengan diperolehnya $t_{\text {hitung }}=3,1821$ dan $t_{\text {tabel }}=2,000$ pada taraf signifikan $5 \%$, sehingga nilait $t_{\text {hitung }}>t_{\text {tabel }}$ yang berarti $H_{a}$ diterima. 2) Adanya kontribusi yang diberikan pengetahuan awal siswa terhadap kemampuan penalaran matematis yakni $12,42 \%$ dan sisanya 87,58\% ditentukan oleh faktor lain. 3) Tidak terdapat interaksi antara model pembelajaran dengan pengetahuan awal terhadap kemampuan penalaran matematis siswa yakni $F_{\text {hitung }}=1,84$ dan $F_{\text {tabel }}=3,18$ nilai $F_{\text {hitung }}<F_{\text {tabel }}$ yang berarti $H_{o}$ diterima. Berdasarkan pemaparan tersebut, secara umum pembelajaran dengan model discovery learning berpengaruh terhadap kemampuan penalaran matematis. Namun, jika ditinjau dari kemampuan awal, penerapan model discovery learning tidak berpengaruh terhadap kemampuan penalaran matematis.
\end{abstract}

Kata kunci: model discovery learning, kemampuan penalaran matematis, pengetahuan awal siswa.

\section{PENDAHULUAN}

Matematika memiliki peran penting dalam dunia pendidikan, karena mampu memberi peluang bagi terbentuknya kemampuan berfikir, berkomunikasi, bernalar secara sistematis serta membentuk sifat positif. Berdasarkan hal itu sangatlah penting bagi kita untuk mempelajarinya dari pendidikan sekolah dasar sampai ke perguruan tinggi. Matematika dapat pula dipandang sebagai cara bernalar, karena matematika memuat cara pembuktian yang valid, serta sifat penalaran matematika yang sistematis. Matematika dan penalaran matematis merupakan dua hal yang tidak dapat dipisahkan, yaitu materi matematika dipahami melalui penalaran dan penalaran dipahami dan dilatihkan melalui belajar materi matematika. Dengan kata lain, belajar matematika tidak terlepas dari aktivitas bernalar.

Pada Peraturan Menteri Pendidikan dan Kebudayaan Republik Indonesia Nomor 58 (2014) dijelaskan bahwa tujuan pembelajaran matematika Sekolah Menengah Pertama (SMP) dan Madrasah Tsanawiyah yaitu agar siswa memiliki kemampuan dalam hal:

1. Mamahami konsep matematika, merupakan kompetensi dalam menjelaskan keterkaitan antarkonsep dan menggunakan konsep maupun algoritma, secara luwes, akurat, efisien, dan tepat, dalam pemecahan masalah. 
2. Menggunakan pola sebagai dugaan dalam penyelesaian masalah, dan mampu membuat generalisasi berdasarkan fenomena atau data yang ada.

3. Menggunakan penalaran dan sifat, melakukan manipulasi matematika baik dalam penyederhanaan, maupun menganalisa komponen yang ada dalam pemecahan masalah dalam konteks matematika maupun di luar matematika (kehidupan nyata, ilmu dan teknologi) yang meliputi kemampuan memahami masalah, membangun model matematika, menyelesaikan model dan menafsirkan solusi yang diperoleh termasuk dalam rangka memecahkan masalah dalam kehidupan sehari-hari.

4. Mengkomunikasikan gagasan, penalaran, serta mampu menyusun bukti matematika dengan menggunakan kalimat lengkap, simbol, tabel, diagram, atau media lain untuk memperjelas keadaan atau masalah.

5. Memiliki sikap menghargai kegunaan matematika dalam kehidupan, yaitu memiliki rasa ingin tahu, perhatian, dan minat dalam mempelajari matematika, serta sikap ulet dan percaya diri dalam pemecahan masalah.

6. Memiliki sikap dan perilaku yang sesuai dengan nilai-nilai dalam matematika dan pembelajarannya, seperti taat azas, konsisten, menjunjung tinggi kesepakatan, toleran, menghargai pendapat orang lain, santun, demokrasi, ulet, tangguh, kreatif, menghargai kemestaan (konteks, lingkungan), kerjasama, adil, jujur, teliti, cermat, bersikap luwes dan terbuka, memiliki kemauan berbagi rasa dengan orang lain.

7. Melakukan kegiatan-kegiatan motorik yang menggunakan pengetahuan matematika.

8. Menggunakan alat peraga sederhana maupun hasil teknologi untuk melakukan kegiatan-kegiatan matematika. Kecakapan atau kemampuan-kemampuan tersebut saling terkait erat, yang satu memperkuat sekaligus membutuhkan yang lain.

Penalaran merupakan proses berpikir dalam proses penarikan kesimpulan. Gardner (Sumarmo, 2013) mengungkapkan bahwa penalaran adalah kemampuan menganalisis, menggeneralisasi, mensistensis atau mengintegrasikan, memberikan alasan yang tepat dan menyelesaikan masalah tidak rutin. Selain itu, Lestari dan Yudhanegara (2017) mengemukakan bahwa penalaran merupakan suatu kegiatan, suatu proses atau suatu aktivitas berpikir untuk menarik kesimpulan atau membuat suatu pernyataan baru yang benar berdasarkan beberapa pernyataan yang kebenarannya telah dibuktikan atau diasumsikan sebelumnya.

Rendahnya kemampuan penalaran matematis siswa akan mempengaruhi kualitas belajar siswa, yang berdampak pada rendahnya prestasi belajar siswa di sekolah. Hal ini terlihat dari prestasi siswa dalam belajar matematika memberikan hasil yang kurang menggembirakan, yang ditunjukkan dengan rendahnya prestasi siswa Indonesia dalam matematika yang diungkapkan oleh hasil tes dan survey PISA 2015 yang menunjukkan Indonesia berada di peringkat 63 dari 69 negara. Pembelajaran matematika yang mengarah kepada meningkatnya kemampuan penalaran sudah semestinya dan diimplementasikan. Berdasarkan uraian di atas, maka diketahui bahwa kemampuan penalaran matematis merupakan kemampuan yang harus ditingkatkan. Namun fakta di lapangan tidak sejalan dengan pentingnya penguasaan kemampuan penalaran matematis.

Berdasarkan hasil wawancara dengan salah satu guru matematika kelas VIII SMP Negeri 3 Tambang yaitu Ibu Maryam S.Pd., diperoleh informasi bahwa kemampuan penalaran matematis siswa masih tergolong rendah. Pernyataan ini sejalan dengan hasil tes yang peneliti terapkan, yaitu berupa soal uraian untuk mengukur kemampuan penalaran matematis siswa dan juga diperoleh hasil yang sama. Hal ini dapat dikemukakan dalam beberapa gejala-gejala sebagai berikut:

1. Kemampuan siswa dalam menyelesaikan soal-soal yang mengarah pada penalaran matematis masih rendah, ditandai dengan sebagian dari siswa belum mampu untuk mengungkapkan ide-ide matematika ke dalam bentuk model, simbol, gambar maupun grafik. 
2. Penyelesain soal yang diberikan oleh guru hanya terpaku pada satu bentuk penyelesaian saja, siswa tidak mampu memperkirakan jawaban berupa alternatif penyelesaian yang lain.

3. Banyak siswa tidak bisa menarik kesimpulan dari cara menyelesaikan suatu soal, mulai dari mengidentifikasi hal-hal yang diketahui, ditanya, kemudian memperjelas langkahlangkah dalam penyelesaiannya secara detail.

Mengatasi rendahnya kemampuan penalaran matematis siswa dalam pembelajaran matematika tersebut, salah satu alternatif cara yang dapat dilakukan adalah dengan menerapkan discovery learning dalam pembelajaran di kelas. Discovery learning merupakan pembelajaran yang mengatur kegiatan didalamnya sedemikian rupa sehingga siswa memperoleh pengetahuan yang sebelumnya belum diketahuinya tidak melalui pemberitahuan, namun ditemukan sendiri. Intinya, model discovery learning mengubah kondisi belajar yang pasif menjadi aktif dan kreatif. Mengubah pembelajaran yang teacher oriented dimana guru menjadi pusat informasi menjadi student oriented; siswa menjadi subjek belajar (Cahyo, 2013). Siswa menemukan pengetahuan tersebut oleh dirinya sendiri dalam proses pembelajaran dan mendapatkannya melalui kesimpulan yang telah dia miliki dari hal-hal yang telah dia temukan.

Pernyataan ini diperkuat oleh hasil penelitian yang dilakukan Nurmini (2016) dengan judul "Pengaruh Penerapan Metode Discovery Learning Terhadap Penalaran Matematika Siswa Di SMP Negeri 23 Pekanbaru". Hasil penelitian tersebut menunjukkan bahwa kemampuan penalaran matematis siswa yang diterapkan model discovery learning mengalami peningkatan dibandingkan dengan kemampuan penalaran matematis siswa yang diterapkan pembelajaran konvensional. Faktor yang juga menentukan keberhasilan siswa dalam menerima pelajaran adalah pengetahuan awal. Dengan mengggunakan pengetahuan awal siswa, dapat diketahui sejauh mana siswa akan dapat mengetahui materi yang telah disajikan.

Menurut Dochy (Prastisi, 2007), pengetahuan awal siswa berkontribusi signifikan terhadap skor-skor pasca tes atau perolehan belajar. Pembelajaran yang berorientasi pada pengetahuan awal akan memberikan dampak pada proses dan perolehan belajar yang memadai.

Lebih lanjut dikemukakan bahwa belajar akan lebih bermakna apabila materi yang dipelajari (hasil belajar berupa konsep atau prinsip) diasumsikan atau dihubungkan dengan pengetahuan yang telah dimiliki siswa dalam bentuk struktur kognitif berupa fakta-fakta, konsepkonsep dan generalisasi yang dipelajari atau diingat oleh siswa. Hal ini juga sejalan dengan pendapat Purwana (2012), yang menyatakan bahwa pentingnya analisis terhadap pengetahuan awal siswa sebelum proses pembelajaran, agar dapat digunakan sebagai bahan dalam merancang pembelajaran yang memandang bahwa belajar adalah proses pembentukan (konstruksi) pengetahuan oleh siswa secara aktif, dan menempatkan guru sebagai mediator dan fasilitator. Berdasarkan paparan tentang pengetahuan awal, dapat disimpulkan bahwa pengetahuan awal merupakan proses bermakna dengan mengaitkan informasi baru pada konsep-konsep yang relevan yang terdapat pada struktur kognitif siswa.

Sehubungan dengan uraian di atas, maka peneliti tertarik melakukan penelitian dengan judul "Pengaruh Penerapan Model Discovery Learning terhadap Kemampuan Penalaran Matematis ditinjau dari Pengetahuan Awal Siswa SMP Negeri 3 Tambang Kabupaten Kampar".

\section{METODE}

Jenis penelitian yang dilakukan adalah Quasi experiment. Jenis ini mempunyai kelompok kontrol, tetapi tidak dapat berfungsi sepenuhnya untuk mengontrol varibel-variabel luar yang mempengaruhi pelaksanaan eksperimen. Desain yang digunakan peneliti adalah the nonequivalent posttest-only control group design (Lestari dan Yudhanegara, 2017. Pada desain ini terdapat dua kelompok yang dipilih secara purposive. Kelompok pertama diberi perlakuan (X) dan kelompok 
yang lain tidak. Kelompok yang diberi perlakuan (X) merupakan kelompok eksperimen sedangkan kelompok yang tidak diberi perlakuan (X) dinamakan dengan kelompok kontrol. Secara rinci desain the nonequivalent posttest-only control group design ini dapat dilihat pada tabel sebagai berikut:

Tabel 1. Rancangan Penelitian

\begin{tabular}{ccc}
\hline Kelompok & Perlakuan & Posttest \\
\hline $\mathrm{K}_{\mathrm{E}}$ & $\mathrm{X}$ & $\mathrm{O}$ \\
$\mathrm{K}_{\mathrm{K}}$ & - & $\mathrm{O}$ \\
\hline Sumber: Karunia Eka Lestari dan Yudhanegara (2017) &
\end{tabular}

Penelitian ini dilaksanakan di SMP Negeri 3 Tambang Desa Kualu Kecamatan Tambang Kabupaten Kampar. Populasi dalam penelitian ini adalah seluruh siswa kelas VIII SMP Negeri 3 Tambang Kecamatan Tambang Kabupaten Kampar tahun pelajaran 2017/2018 yang berjumlah 202 siswa yang terdiri dari 7 kelas yaitu kelas $\mathrm{VIII}^{1}, \mathrm{VIII}^{2}, \mathrm{VIII}^{3}, \mathrm{VIII}^{4}, \mathrm{VIII}^{5}$, $\mathrm{VIII}^{6}$ dan $\mathrm{VIII}^{7}$. Pengambilan sampel ini dilakukan menggunakan teknik purposive sampling, yaitu teknik pengambilan sampel dengan pertimbangan tertentu (Lestari dan Yudhanegara, 2017). Oleh karena itu dari seluruh kelas VIII diambil dua kelas untuk dijadikan sampel dalam penelitian ini yaitu kelas VIII ${ }^{4}$ untuk dijadikan kelas eksperimen dan kelas VIII $^{2}$ untuk dijadikan kelas kontrol dengan pertimbangan bahwa kedua kelas tersebut memiliki karakteristik yang relatif homogen dari segi kemampuan penalaran matematisnya dan kedua kelas tersebut sebelumnya diajarkan oleh guru yang sama sesuai dengan yang disarankan oleh guru bidang studi matematika. Sebelum sampel diberi perlakuan, maka kedua kelas yaitu kelas eksperimen dan kelas kontrol diberikan tes pengetahuan awal siswa dan dianalisis terlebih dahulu melalui uji normalitas, uji homogenitas dan uji-t untuk membuktikan kedua sampel dalam keadaan awal yang sama atau relatif homogen.

Pengumpulan data merupakan suatu kegiatan mencari data di lapangan yang akan digunakan untuk menjawab permasalahan penelitian (Lestari dan Yudhanegara, 2017). Peneliti menggunakan 3 teknik pengumpulan data yaitu teknik observasi, teknik dokumentasi, dan teknik tes.

Peneliti melakukan teknik observasi dengan menggunakan lembar observasi yang telah disediakan. Observasi dilakukan peneliti dan dibantu oleh observer yang merupakan guru bidang studi matematika disekolah untuk mengamati kegiatan yang dilakukan oleh peneliti dan siswa saat pembelajaran berlangsung. Teknik ini menggunakan instrumen lembar observasi aktivitas guru dan siswa.

Teknik dokumentasi ini dilakukan untuk mengetahui sejarah sekolah, keadaan guru dan siswa, sarana dan prasarana serta memperoleh data nama-nama siswa untuk melihat pengetahuan awal siswa. Selain itu peneliti juga menggunakan cara mengambil foto dalam kegiatan pembelajaran sebagai pendokumentasian dalam penelitian. Oleh karena itu, instrument pengumpulan data menggunakan teknik ini adalah berupa dokumentasi kondisi sekolah serta foto dan video keterlaksanaan penelitian.

Teknik tes adalah serangkaian pertanyaan atau latihan serta alat lain yang digunakan untuk mengukur keterampilan, pengetahuan intelegensi, kemampuan atau bakat yang dimiliki individu atau kelompok (Riduwan, 2013). Instrumen yang digunakan untuk memperoleh data tentang hasil belajar matematika pada kelas kontrol dan kelas eksperimen terutama dalam aspek penalaran matematis pengumpulan data menggunakan tes pengetahuan awal dan posttest. Tes berbentuk uraian yang diberikan pada awal dan akhir penelitian. Tujuan dari tes ini adalah untuk menjawab hipotesis penelitian yang telah dirumuskan sebelumnya.

Sebelum tes dilakukan, soal tes terlebih dahulu diujikan kepada siswa kelas IX SMP Negeri 3 Tambang. Tes tersebut harus memenuhi persyaratan. Adapun persyaratan tersebut antara lain: validitas butir soal, reliabilitas soal, daya pembeda soal, dan tingkat kesukaran. 
Rangkuman validitas, reliabilitas, daya pembeda dan tingkat kesukaran soal terlihat pada tabel 2 berikut:

Tabel 2. Rangkuman Analisis Butir Soal Tes Pengetahuan Awal

\begin{tabular}{|c|c|c|c|c|c|c|}
\hline No & $\begin{array}{c}\text { Nomor } \\
\text { Soal }\end{array}$ & $\begin{array}{l}\text { Validitas } \\
\text { Soal }\end{array}$ & Reliabilitas & $\begin{array}{c}\text { Daya } \\
\text { pembeda } \\
\text { Soal } \\
\end{array}$ & $\begin{array}{c}\text { Tingkat } \\
\text { Kesukaran } \\
\text { Soal }\end{array}$ & Keterangan \\
\hline 1 & 1 & $\begin{array}{l}\text { Cukup } \\
\text { Tinggi }\end{array}$ & & Cukup & Sedang & Digunakan \\
\hline 2 & 2 & Tinggi & & Baik & Sedang & Digunakan \\
\hline 3 & 3 & $\begin{array}{l}\text { Sangat } \\
\text { Rendah }\end{array}$ & & Jelek & Mudah & $\begin{array}{c}\text { Tidak } \\
\text { Digunakan }\end{array}$ \\
\hline 4 & 4 & Rendah & Baik & Cukup & Sukar & Digunakan \\
\hline 5 & 5 & Tinggi & & Cukup & Sedang & Digunakan \\
\hline 6 & 6 & $\begin{array}{l}\text { Cukup } \\
\text { Tinggi }\end{array}$ & & Baik & Mudah & Digunakan \\
\hline 7 & 7 & $\begin{array}{l}\text { Cukup } \\
\text { Tinggi }\end{array}$ & & Cukup & Sedang & Digunakan \\
\hline
\end{tabular}

Sedangkan hasil rangkuman analisis instrumen soal posttest dapat dilihat pada tabel 3 sebagai berikut:

Tabel 3. Rangkuman Analisis Butir Soal Posttest

\begin{tabular}{ccccccc}
\hline No & $\begin{array}{c}\text { Nomor } \\
\text { Soal }\end{array}$ & $\begin{array}{c}\text { Validitas } \\
\text { Soal }\end{array}$ & Reliabilitas & $\begin{array}{c}\text { Daya } \\
\text { pembeda } \\
\text { Soal }\end{array}$ & $\begin{array}{c}\text { Tingkat } \\
\text { Kesukaran } \\
\text { Soal }\end{array}$ & Keterangan \\
\hline 1 & 1 & Cukup & Cukup & Mudah & Digunakan \\
2 & 2 & Tinggi & Cukup & Sedang & Digunakan \\
3 & 3 & Rendah & & Jelek & Mudah & Tidak \\
4 & 4 & Tinggi & Cukup Baik & Jelek & Sedang & Digunakan \\
5 & 5 & Tinggi & & Cukup & Sedang & Digunakan \\
6 & 6 & Tinggi & & Cukup & Sedang & Digunakan \\
7 & 7 & Sangat Tinggi & Cukup & Sedang & Digunakan \\
\hline
\end{tabular}

Berdasarkan tabel 2 dan tabel 3, dapat disimpulkan dari 7 butir soal pengetahuan awal dan posttest peneliti menggunakan 6 butir soal untuk diujikan dikelas eksperimen dan kelas kontrol. Soal yang digunakan untuk diujikan di kelas eksperimen dan kontrol yaitu soal nomor 1, 2, 4, 5, 6 dan 7.

Teknik analisis data yang digunakan pada penelitian ini menggunakan uji statistik inferensial. Adapun uji statistik yang digunakan yaitu uji-t dan uji ANOVA dua arah.

\section{HASIL DAN PEMBAHASAN}

\section{Hasil}

\section{Analisis Data Pengetahuan Awal Siswa}

Hasil perhitungan uji normalitas pengetahuan awal siswa menggunakan rumus Chi Kuadrat, disajikan pada tabel 4 sebagai berikut: 
Tabel 4. Hasil Uji Normalitas Pengetahuan Awal Siswa

\begin{tabular}{lccc}
\hline Kelas & $\boldsymbol{\chi}_{\text {hitung }}^{\mathbf{2}}$ & $\boldsymbol{\chi}_{\text {tabel }}^{\mathbf{2}}$ & Kriteria \\
\hline Eksperimen & 4,2006 & 11,070 & Normal \\
Kontrol & 1,0436 & 11,070 & Normal \\
\hline
\end{tabular}

Bedasarkan tabel 4, tampak bahwa perhitungan data sebelum perlakuan untuk kelas eksperimen diperoleh $\chi_{\text {hitung }}^{2}$ sebesar 4,2006 dengan $\chi_{\text {tabel }}^{2}$ dalam taraf signifikan 5\% sebesar 11,070. Kemudian untuk kelas kontrol $\chi_{\text {hitung }}^{2}$ yang diperoleh sebesar 1,0436 dengan $\chi_{\text {tabel }}^{2}$ dalam taraf signifikan 5\% sebesar 11,070. Karena $\chi_{\text {bitung }}^{2}<\chi_{\text {tabel, }}^{2}$ maka data berdistribusi normal. Oleh karena itu, dapat disimpulkan bahwa data hasil tes pengetahuan awal siswa kelas eksperimen dan kelas kontrol sebelum perlakuan berdistribusi normal.

Selanjutnya, peneliti melakukan uji homogenitas terhadap hasil pengetahuan awal menggunakan uji varians terbesar dibanding varians terkecil. Setelah dilakukan analisis menggunakan uji varians terbesar dibanding varians terkecil, diperoleh nilai $F_{\text {hitung }}$ yaitu 1,16 sedangkan untuk nilai $F_{\text {tabel }}$ yaitu 1,87 maka $F_{\text {hitung }}<F_{\text {tabel }}$. Oleh karena itu, dapat disimpulkan bahwa varians kedua kelas tersebut adalah homogen.

Setelah memenuhi kedua syarat yaitu data harus homogen dan berdistribusi normal, dapat dilanjutkan dengan melakukan test-t terhadap hasil pengetahuan awal siswa. Berdasarkan hasil analisis test- $t$ diperoleh nilai $t_{\text {hitung }}=0,4322$. Dilanjutkan dengan menentukan $d k$ dengan rumus $d k=N_{x}+N_{y}-2=28+29-2=55$ dan dikonsultasikan pada tabel nilai $t_{\text {tabel }}$. Dengan $d k=55$ dan taraf signifikan $5 \%$ di peroleh $t_{\text {tabel }}=2,000$. Dengan demikian, karena $t_{\text {hitung }}<t_{\text {tabel }}$, maka dapat disimpulkan bahwa tidak terdapat perbedaan antara siswa kelas eksperimen dan kelas kontrol. Oleh karena itu, dapat disimpulkan bahwa kedua kelas yang dipilih adalah kelas yang setara kemampuan awalnya.

\section{Analisis Data Penalaran Matematis Siswa}

Hasil perhitungan uji normalitas kemampuan penalaran matematis siswa menggunakan rumus $C h i$ Kuadrat, disajikan pada tabel 5 sebagai berikut:

Tabel 5. Hasil Uji Normalitas Posttest

\begin{tabular}{cccc}
\hline Kelas & $\chi_{\text {hitung }}^{2}$ & $\chi_{\text {tabel }}^{2}$ & Kriteria \\
\hline Eksperimen & 6,9571 & 11,070 & Normal \\
Kontrol & 2,3585 & 11,070 & Normal \\
\hline
\end{tabular}

Berdasarkan tabel 5 di atas, karena $\chi_{\text {bitung }}^{2}<\chi_{\text {tabel, }}^{2}$ maka data berdistribusi normal. Oleh karena itu, dapat disimpulkan bahwa data kelas eksperimen dan kelas kontrol setelah diberikan perlakuan berdistribusi normal. Selanjutnya, uji homogenitas posttest yang peneliti lakukan menggunakan uji varians terbesar dibanding varians terkecil. Berdasarkan analisis tersebut, diperoleh nilai $\chi_{\text {hitung }}^{2}=1,76$, sedangkan nilai $\chi_{\text {tabel }}^{2}=1,88$. Maka nilai $\chi_{\text {hitung }}^{2}<\chi_{\text {tabel }}^{2}$. Oleh karena itu, dapat disimpulkan bahwa varians tersebut adalah homogen.

Langkah selanjutnya, untuk mengetahui perbedaan kemampuan penalaran matematis dari kedua kelompok sampel maka data yang diperoleh dari hasil posttest dianalisis menggunakan analisis data dengan test " $t$ ". Hasil uji tes " $\mathrm{t}$ " dapat dilihat pada tabel 6 sebagai berikut: 
Tabel 6.Hasil Uji Test “t” Posttest

\begin{tabular}{ccc}
\hline $\boldsymbol{t}_{\text {hitung }}$ & $\boldsymbol{t}_{\text {tabel }} \mathbf{5} \%$ & Keterangan \\
\hline 3,1821 & 2,000 & $H_{a}$ diterima \\
\hline
\end{tabular}

Berdasarkan hasil perhitungan, nilai $t_{\text {hitung }}=3,1821$ sedangkan nilai tabel dengan derajat kebebasan $d k=N_{x}+N_{y}-2=28+29-2=55$. Namun dalam tabel tidak terdapat $d k=$ 55 , maka dari itu digunakan $d k$ yang mendekati 55 yaitu $d k=60$. Jika dilihat pada $t_{\text {tabel }}$, pada taraf signifikan $5 \%$ adalah 2,000 hal ini berarti bahwa $t_{\text {hitung }}>t_{\text {tabel }}$. Maka dapat ditarik kesimpulan bahwa $H_{o}$ ditolak dan $H_{a}$ diterima yang berarti "terdapat perbedaan penalaran matematis antara siswa yang diterapkan model discovery learning dengan siswa yang tidak diterapkan model discovery learning"

\section{Hasil Uji Korelasi (Pearson Product Moment)}

Uji korelasi digunakan untuk mengetahui berapa besar kontribusi pengetahuan awal siswa terhadap penalaran matematis siswa. Berdasarkan perhitungan diperoleh $r_{x y}=0,654801094$ untuk kelas eksperimen dan $r_{x y}=0,177529482$ untuk kelas kontrol. Sedangkan secara umum yakni $r_{x y}=0,352402455$. Maka mencari besarnya kontribusi pengetahuan awal siswa terhadap penalaran matematis yakni:

$$
K P_{u m u m}=(0,352402455)^{2} \times 100 \%=12,42 \%
$$

Artinya pengetahuan awal siswa memberikan kontribusi terhadap penalaran matematis sebesar $12,42 \%$ dan sisanya $87,58 \%$ kontribusi dari factor lainnya.

\section{Hasil Uji Anova Dua Jalan}

Hasil uji anova dua jalan dapat dilihat pada tabel 7 sebagai berikut:

Tabel 7. Hasil Uji Anova Dua Jalan

\begin{tabular}{cccccc}
\hline Sumber Variasi & Dk & Jumlah Kuadrat & $\begin{array}{c}\text { Mean } \\
\text { Kuadrat }\end{array}$ & Fh & Ft \\
\hline Antar kolom & 2 & 3831,44195 & 1915,72 & 25,45 & 3,18 \\
Antar baris & 1 & 1461,64171 & 1461,64 & 19,42 & 4,03 \\
Interaksi (baris x & 2 & 276,5119943 & 138,25 & 1,84 & 3,18 \\
kolom) & 51 & 3838,123642 & 75,26 & & \\
Dalam & 56 & 9407,719298 & & & \\
Total & & &
\end{tabular}

Setelah dilakukan perhitungan uji anova dua jalan, diperoleh interpretasi sebagai berikut:

1) Untuk kolom (antar tingkat pengetahuan awal), harga $F_{\text {hitung }}>F_{\text {tabel }}$ yaitu 25,45 $>$ 3,18 . Hal ini berarti terdapat pengaruh pengetahuan awal terhadap kemampuan penalaran matematis siswa.

2) Untuk baris (antara kelas eksperimen dan kelas control), harga $F_{\text {hitung }}>F_{\text {tabel }}$ yaitu 19,42 > 4,03. Hal ini berarti terdapat perbedaan kemampuan penalaran matematis antara kelas eksperimen dan kelas kontrol.

3) Untuk interaksi, harga $F_{\text {hitung }}<F_{\text {tabel }}$ yaitu 1,84 $<3$,18. Dengan demikian $\mathrm{H}_{\mathrm{a}}$ ditolak dan $\mathrm{H}_{0}$ diterima. Hal ini berarti tidak terdapat interaksi antara pembelajaran menggunakan model discovery learning dengan pengetahuan awal dalam meningkatkan kemampuan penalaran matematis siswa. 


\section{Pembahasan}

Berdasarkan nilai pengetahuan awal siswa pada materi prasyarat bangun ruang kubus dan balok sebelum perlakuan menunjukkan bahwa tidak ada perbedaan jika dilihat dari mean kelas eksperimen dan kelas kontrol yaitu kelas eksperimen senilai 71,93 dan kelas kontrol senilai 73, 62. Hasil pengujian hipotesis dapat dilihat dari nilai $\boldsymbol{t}_{\boldsymbol{h i t u n g}}=\mathbf{0 , 4 3 2 2}$ dan $\boldsymbol{t}_{\text {tabel }}=$ 2,000 pada taraf signifikan 5\%. Maka nilai $\boldsymbol{t}_{\text {hitung }}<\boldsymbol{t}_{\text {tabel }}$ yang berarti $\boldsymbol{H}_{\boldsymbol{o}}$ diterima dan $\boldsymbol{H}_{\boldsymbol{a}}$ ditolak. Artinya, sebelum diberikan perlakuan, kedua kelas yang dipilih sebagai kelas eksperimen dan kelas kontrol berada dalam kondisi awal yang sama.

Sedangkan setelah perlakuan, berdasarkan hasil pengujian hipotesis yang diperoleh menunjukkan bahwa terdapat perbedaan antara siswa yang diterapakan model discovery learning dengan siswa yang tidak diterapkan model discovery learning. Adanya perbedaan menunjukkan model discovery learning berpengaruh terhadap kemampuan penalaran matematis. Perbedaan mean kelas eksperimen dan kelas kontrol yaitu kelas eksperimen menerapkan model discovery learning adalah 83,75 dan kelas kontrol tidak diterapkan model dicovery learning adalah 73,79. Hasil pengujian hipotesis dapat dilihat dari nilai $t_{\text {hitung }}=3,1821$ dan $t_{\text {tabel }}=2,000$ pada taraf signifikan $5 \%$ atau $t_{\text {hitung }}>t_{\text {tabel }}$ yang berarti $H_{o}$ ditolak dan $H_{a}$ diterima yang berarti "terdapat perbedaan penalaran matematis antara siswa yang diterapkan model discovery learning dengan siswa yang tidak diterapkan model discovery learning". Perbedaan ini juga dapat dilihat dari uji pasca anova yaitu 19,42 dengan banyak sampel 28 kelas eksperimen dan 29 kelas kontrol. Maka hasil dari pasca anova dengan RKd yaitu 75,26 hasil uji lanjutan ini akan dibandingkan dengan rata-rata antar kelompok sebagai berikut:

Tabel 8. Hasil Uji Lanjutan

\begin{tabular}{cccc}
\hline HSD & Rata-rata & Perbandingan & Kesimpulan \\
\hline \multirow{2}{*}{3,1821} & Eksperimen $=83,75$ & $3,1821<83,75$ & Terdapat perbedaan signifikan \\
& Kontrol $=73,79$ & $3,1821<73,79$ & Terdapat perbedaan signifikan \\
\hline
\end{tabular}

Berdasarkan tabel di atas, tampak bahwa terdapat kontribusi yang diberikan pengetahuan awal siswa terhadap kemampuan penalaran matematis. Kontribusi ini sebesar $12,42 \%$ dan sisanya $87,58 \%$ ditentukan oleh faktor lain.

Selanjutnya, untuk melihat adanya interaksi antara model discovery learning dengan pengetahuan awal siswa diperoleh nilai $F_{h}$ adalah $1,84 . F_{t}$ dengan $d k=2$ untuk pembilang dan 60 untuk penyebut, diperoleh 3,18 pada taraf signifikan 5\%. Maka nilai $F_{h}<F_{t}$ yang berarti $H_{o}$ diterima dan $H_{a}$ ditolak. Hal ini berarti hipotesis yang menyatakan $H_{o}$ diterima, artinya tidak terdapat interaksi antara model pembelajaran dengan pengetahuan awal siswa.

Selain itu, selama kegiatan eksperimen berlangsung, kegiatan guru dinilai melalui lembar observasi yang telah dipersiapkan oleh peneliti sebelumnya. Lembar observasi berisi uraian kegiatan yang harus dilaksanakan guru selama proses pembelajaran berlangsung. Dari hasil penilaian, dapat diketahui bahwa aktivitas yang dilakukan guru sudah terlaksana dengan baik dalam menggunakan penerapan model discovery learning. Hasil observasi terangkum pada tabel 9 sebagai berikut: 
Tabel 9. Hasil Observasi Aktivitas Guru pada Kelas Eksperimen

\begin{tabular}{|c|c|c|c|c|c|c|}
\hline \multirow{2}{*}{ No } & \multirow{2}{*}{ Jenis Aktivitas Guru } & \multicolumn{5}{|c|}{ Pertemuan Ke- } \\
\hline & & I & II & III & IV & $\mathbf{V}$ \\
\hline 1 & Guru mengecek kemampuan prasyarat siswa & 3 & 4 & 4 & 4 & 4 \\
\hline 2 & $\begin{array}{l}\text { Guru menyampaikan inti materi, tujuan dan teknik } \\
\text { pembelajaran yang dilakukan }\end{array}$ & 4 & 4 & 4 & 4 & 4 \\
\hline 3 & $\begin{array}{l}\text { Mengkondisikan siswa ke dalam kelompok belajar dan } \\
\text { membagikan Lembar Kerja Siswa (LKS) }\end{array}$ & 3 & 4 & 4 & 4 & 4 \\
\hline 4 & $\begin{array}{l}\text { Menghadapkan siswa pada situasi yang menimbulkan rasa } \\
\text { ingin tahu siswa }\end{array}$ & 2 & 3 & 3 & 3 & 4 \\
\hline 5 & $\begin{array}{l}\text { Membimbing siswa dalam mengidentifikasi hal-hal yang } \\
\text { berkaitan dengan penalaran dan relevan dengan materi } \\
\text { pelajaran }\end{array}$ & 3 & 3 & 4 & 4 & 4 \\
\hline 6 & $\begin{array}{l}\text { Membimbing siswa dalam mengumpulkan dan mengolah } \\
\text { informasi-informasi yang di dapat pada LKS }\end{array}$ & 4 & 4 & 4 & 4 & 4 \\
\hline 7 & $\begin{array}{l}\text { Mengarahkan siswa dalam diskusi dan presentasi hasil } \\
\text { kerja kelompok }\end{array}$ & 4 & 4 & 4 & 4 & 4 \\
\hline 8 & $\begin{array}{l}\text { Guru mengajak siswa untuk menganalisis dan berdiskusi } \\
\text { terhadap hasil kelompok penyaji }\end{array}$ & 4 & 4 & 4 & 4 & 4 \\
\hline 9 & $\begin{array}{l}\text { Guru memberikan penegasan dan klarifikasi terhadap } \\
\text { hasil diskusi kelompok }\end{array}$ & 4 & 4 & 4 & 4 & 4 \\
\hline 10 & $\begin{array}{l}\text { Membimbing siswa untuk menarik kesimpulan dari } \\
\text { pembelajaran }\end{array}$ & 3 & 3 & 4 & 4 & 4 \\
\hline 11 & $\begin{array}{l}\text { Guru mengarahkan siswa untuk mengerjakan latihan } \\
\text { secara individu }\end{array}$ & 3 & 3 & 3 & 4 & 4 \\
\hline & Skor & 37 & 40 & 42 & 43 & 44 \\
\hline & Persentase & 84,10 & 90,91 & 95,45 & 97,73 & 100 \\
\hline & Rata-rata Ativitas Guru Kelas Eksperimen & & & $93,64 \%$ & & \\
\hline
\end{tabular}

Kegiatan pembelajaran juga dipandang dari aktivitas siswa. Aktivitas siswa merupakan kegiatan siswa selama proses pembelajaran yang menggunakan model discovery learning yang dilaksanakan oleh peneliti dinilai melalui lembar observasi siswa. Hal ini bertujuan agar peneliti bisa melihat sejauh mana perkembangan siswa selama belajar dengan model discovery learning. Jika perkembangan siswa dirasa sudah baik dengan ditandai meningkatnya kemampuan penalaran matematis siswa maka eksperimen bisa dihentikan.

Berdasarkan lembar observasi siswa, dari pertemuan pertama hingga pertemuan kelima aktivitas siswa semakin baik, walaupun di pertemuan pertama masih banyak siswa yang kebingungan dengan model discovery learning, tetapi pada pertemuan selanjutnya siswa telah terbiasa, dan bisa dikatakan pembelajaran dengan penerapan model discovery learning sudah terlaksana dengan baik. Hasil observasi siswa terangkum pada tabel 10 sebagai berikut:

Tabel 10. Hasil Observasi Aktivitas Siswa pada Kelas Eksperimen

\begin{tabular}{|c|c|c|c|c|c|c|}
\hline \multirow{2}{*}{ No } & \multirow{2}{*}{ Jenis Aktivitas Siswa } & \multicolumn{5}{|c|}{ Keterangan } \\
\hline & & $\mathbf{I}$ & II & II & IV & $\mathbf{V}$ \\
\hline 1 & $\begin{array}{l}\text { Siswa menjawab pertanyaan untuk mengecek } \\
\text { kemampuan prasyarat }\end{array}$ & 3 & 4 & 4 & 4 & 4 \\
\hline 2 & $\begin{array}{l}\text { Siswa memperhatikan inti materi, tujuan dan teknik } \\
\text { pembelajaran yang akan dilakukan }\end{array}$ & 4 & 4 & 4 & 4 & 4 \\
\hline 3 & Mengkondisikan diri untuk belajar dalam kelompok & 3 & 4 & 4 & 4 & 4 \\
\hline 4 & $\begin{array}{l}\text { Mengamati dan mencermati permasalahan yang } \\
\text { terdapat pada LKS secara berkelompok }\end{array}$ & 3 & 3 & 4 & 4 & 4 \\
\hline 5 & $\begin{array}{l}\text { Mengidentifikasi hal-hal yang berkaitan dengan } \\
\text { penalaran dan relevan dengan materi }\end{array}$ & 3 & 3 & 3 & 3 & 4 \\
\hline 6 & $\begin{array}{l}\text { Menyimpulkan dan mengolah informasi-informasi } \\
\text { untuk pembentukan penalaran }\end{array}$ & 3 & 3 & 3 & 3 & 4 \\
\hline 7 & $\begin{array}{l}\text { Berdiskusi mengenai permasalahan dan melakukan } \\
\text { presentasi kelompok }\end{array}$ & 4 & 4 & 4 & 4 & 4 \\
\hline 8 & Siswa menganalisis dan berdiskusi terhadap hasil & 4 & 4 & 4 & 4 & 4 \\
\hline
\end{tabular}




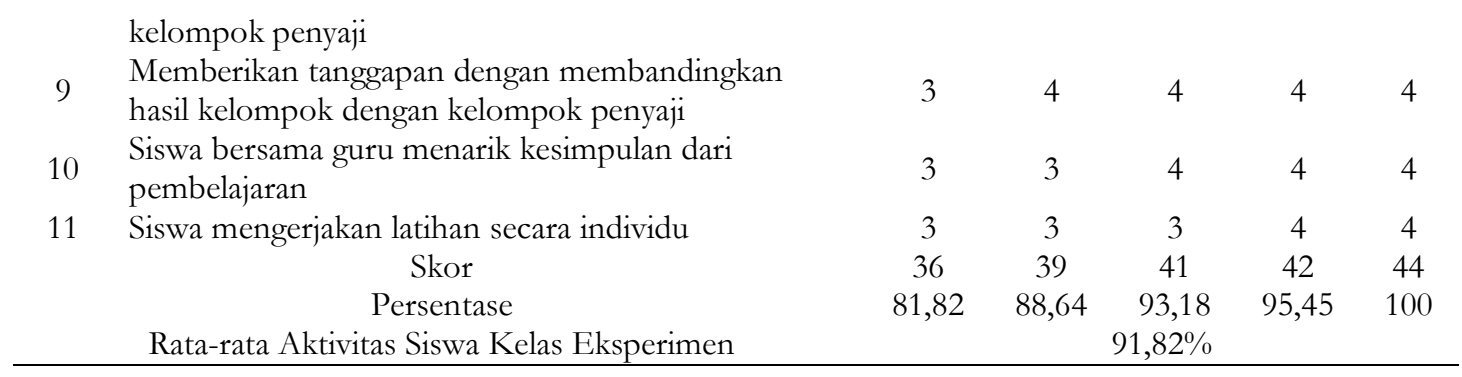

\section{KESIMPULAN}

Berdasarkan hasil penelitian yang dilaksanakan di SMP Negeri 3 Tambang, maka dapat simpulkan bahwa:

1. Terdapat perbedaan kemampuan penalaran matematis antara siswa yang diterapkan model discovery learning dengan siswa yang tidak diterapkan model discovery learning.

2. Adanya kontribusi yang diberikan pengetahuan awal terhadap kemampuan penalaran matematis siswa.

3. Tidak terdapat interaksi antara model pembelajaran dengan pengetahuan awal terhadap kemampuan penalaran matematis siswa.

Dari kesimpulan 1 dan 2, dapat dilihat terdapat perbedaan kemampuan penalaran matematis antara siswa yang diterapkan model discovery learning dengan siswa yang tidak diterapkan model discovery learning dan adanya kontribusi yang diberikan pengetahuan awal terhadap kemampuan penalaran matematis siswa. Karena terdapat perbedaan maka dapat disimpulkan bahwa terdapat "Pengaruh Penerapan Model Discovery Learning terhadap Kemampuan Penalaran Matematis Ditinjau dari Pengetahuan Awal Siswa SMP Negeri 3 Tambang Kabupaten Kampar".Namun, ketiga faktor tidak terdapat interaksi.

\section{REFERENSI}

Cahyo, Agus N. (2013). Panduan Aplikasi Teori-Teori Belajar Mengajar Teraktual dan Terpopuler. Yogyakarta: Diva Press.

Kementrian Pendidikan dan Kebudayaan, Peraturan Menteri Pendidikan dan Kebudayaan Republik Indonesia Nomor 58 Tahun 2014, Jakarta.

Lestari, Karunia Eka dan Yudhanegara, Mokhammad Ridwan. (2017). Penelitian Pendidikan Matematika. Bandung: Refika Aditama.

Nurmini. (2016). Pengaruh Penerapan Metode Discovery Learning terhadap Kemampuan Penalaran Matematika Siswa Dd SMP Negeri 23 Pekanbaru. Pekanbaru: UIN SUSKA RIAU.

Riduwan. (2013). Belajar Mudah Penelitian untuk Guru, Karyawan, dan Peneliti Pemula. Bandung: Alfabeta.

Sumarmo, Utari. (2013). Kumpulan Makalab Berpikir dan Disposisi Matematik serta Pembelajarannya. Bandung: Jurusan Pendidikan Matematika FMIPA-UPI.

Survey Internasioanal PISA diakses dari www.ubaya.ac.id/2014/content/ articles_detail/230/Overview-of-the-PISA-2015-result-that-have-just-been-Released.html

Prastisi, Tri Dyah. (2007). Pengaruh Pendekatan Pembelajaran RME dan Pengetahuan Awal terhadap Kemampuan Komunikasi dan Pemahaman Matematika Siswa SMP Kelas VII, Jurnal Didaktika, Vol. 2, No. 1.

Purwana, Unang. (2012). Profil Pengetahuan Awal (Prior Knowledge) Siswa SMP Tentang Konsep Kemagnetan. Jurnal MIPA, Vol. 13, No. 2. 